\title{
Pampa Biome Native Plant Appreciation by the Analysis of Glandularia peruviana (L.) Cuttings Growth
}

\author{
Luciana Dall'Agnese, Cláudia Petry, Paloma Alves da Silva Sexto \\ Graduate Program in Agronomy, School of Agronomy and Veterinary Medicine, University of Passo Fundo, \\ Passo Fundo, Brazil \\ Email: dallagnese.lu@hotmail.com
}

Received 13 January 2015; accepted 9 February 2015; published 25 February 2015

Copyright @ 2015 by authors and Scientific Research Publishing Inc.

This work is licensed under the Creative Commons Attribution International License (CC BY). http://creativecommons.org/licenses/by/4.0/

c) (†) Open Access

\section{Abstract}

A native plant of Biome Pampa (Southern Brazil), the Glandularia peruviana (L.) Small species has been, until now, little studied as ornamental plant for use as mulch and formation of massifs. Whilst this species didn't suffer any genetic improvement process, it is extremely ornamental by its color and size. In order to promote its comercial propagation and its use to improve the Pampa biodiversity, this study was conducted to know, as a ruderal plant native from South America, how the behavior of the plants was when employed plant propagation and use of artificial auxin on the cuttings. The test consisted of assessing the growth of cuttings treated or not with indol-butyric acid, analyzed at diferent ages, at 21, 24, 27 and 31 days in the University of Passo Fundo, Passo Fundo, Brazil. It was observed that the plant total dry mass values showed no standard of behavior, values for dry matter, whether of leaves, stem, root, shoot and total not responded to treatments and analyzed ages. The same occurred for specific leaf weight, plant height, number of green leaves, number of dead leaves, average leaf length and average number of stems. The lack of significant treatment and age effects may be explained by the plant primitiveness, which is ruderal, so its development has little influenced by the propagation practices.

\section{Keywords}

Glandularia peruviana, Indol-Butyric Acid, Native, Plant Age, Propagation, Ruderal

\section{Introduction}

The Glandularia J.F. Gmel. (Verbenaceae) genus presents nearly 80 species distributed in subtropical and 
temperate regions of South America and North America [1]. The genus consists of perennial herbs or subshrubs, erect, prostrate or creeping plants, with radicantes nodes or not and with ascending flowering stems. The plants grow principally on grasslands, meadows, ravines along the road and forest borders [2].

The species G. peruviana (L.) Small occurs in several countries in South America, being spontaneous in sandy and rocky soils and in fields of Rio Grande do Sul, Brazil [1]. It is known for its medicinal potential, as febrifuge and stimulant when ingested as tea and as healing in topical use [3]. It differs from other Glandularia species by having red corolla, though, it has already found with corolla lighter reds, coming to white near the corolla center. It flowers and fruits from September to April [1].

This species is still considered a wild species and not suffered any genetic improvement process to amend vegetative growth and flowering characteristics yet, it has very showy and harmonious flowers for their size and color. The ornamental value of G. peruviana was characterized by evaluating the behavior of the species after 100 days in vase, in this study, after the specified time, the plants covered $75 \%$ of the size of the pot and had semi-erect and decumbent behavior [4].

Regarding the applicability of landscape Glandularia sp. for use in flower bed, it was observed large emission of stolons with average diameter of $49.03 \mathrm{~cm}$ and $100 \%$ cover of the bed after 105 cultivation days, so it highlights the studied species for use as mulch and formation of massifs, primarily for public areas, downhill and/or degraded soil [5].

Economically, the vegetative propagation is considered a low cost and effective alternative and strategy in the preservation of endangered and/or restritctive germination native plants [6]. There are few studies to G. peruviana as a plant for ornamental use, being inexistent a protocol for vegetative propagation that make its production viable, efficient and low cost, to the regional market. This experiment is part of a project to create a sustainable protocol for $G$. peruviana comercial production.

When tested the survival of cuttings of three species of Glandularia, G. peruviana was the only one not responding to hormone doses used, with maximum rooting of 52.2\% [4]. The indol-butyric acid (IBA) is one of the most used auxin in reproduction by cuttings because of its high effectiveness, a greater range of nonphytotoxic concentrations and be active in many species, it is a photostable substance, with localized action and less sensitive to biological degradation when compared to other synthetic auxin [7].

Based in [4], which demonstrates that the species is not influenced by auxin on survival of cuttings, it sought, through this work, to evaluate the hypothesis that there is no influence of IBA on growth of cuttings of $G$. peruviana along time.

\section{Methods}

\subsection{Location}

The study area is located in Rio Grande do Sul State (RS) at extreme South of Brazil, in Passo Fundo $\left(52^{\circ} 24^{\prime} \mathrm{W}\right.$, $\left.28^{\circ} 15^{\prime} \mathrm{S}\right), 687 \mathrm{~m}$ above sea level, at Universidade de Passo Fundo.

\subsection{Plant Material}

The Glandularia peruviana (L.) Small cuttings was proceeded at 1 November 2013, using herbal cuttings (apical and medium) with $10 \mathrm{~cm}$ long and 3 nodes per cutting, with 6 leaves per cutting, from plant matrixes from Coronel Barros (54 $\left.03^{\prime} \mathrm{W}, 28^{\circ} 22^{\prime} \mathrm{S}\right), 311 \mathrm{~m}$.

\subsection{Cultivation}

A blend of carbonized rice husk and comecial organic compost Humosolo ${ }^{\circledR}$ at 2:1 proportion was employed as rooting substrate. The cuttings had grown under plastic greenhouse, without temperature control, with 8 seconds nebulization at each 10 minutes period, under shading fabric and without fertilization.

\subsection{Experimental Treatment and Design}

The experimental design was a randomized block design with two treatments and three replications (3 blocks $\times$ 2 treatments $\times 4$ ages) totaling 24 plants. The control cuttings had their base immersed in distilled water, while the treated cuttings had their base immersed in ethanolic solution of IBA ( 500 ppm) by 5 seconds and, after that, buried at $1.5 \mathrm{~cm}$ deep. 
Plants were destructively collected at 21, 24, 27 and 31 days after propagation.

\subsection{Analysed Variables}

The variables evaluated were plant height, live leaves average number per cutting, dead leaves average number per cutting, average leaf length, shoots number, dry mass of leaves, stems, aerial part, root and total, leaf area, leaf area ratio, absolut growth rate, relative growth rate, liquid assimilation rate. The values were compared by the ANOVA method.

\section{Results and Discussion}

It was observed that for both treatments and for the age when the cuttings were collected there were no significant differences visually (Figures 1(a)-(h)), i.e. the plants were similar in appearance.

No significant results, in relation to plant height, were obtained. The same occurred with live leaves average number per cutting, dead leaves average number per cutting, average leaf length and the number of shoots, all parameters had no significant effect by time of analysis or treatment with IBA (Table 1).

In vitro propagation of $G$. peruviana was already protocolled assessing means of establishment and proliferation in vitro, as the establishment in vitro, the culture media without growth regulators was the most effective treatment [8]. These results obtained in [8] confirmed that the use of auxin have not efficient effect at species propagation. It is observed that the values of dry mass of plants showed no standard of behavior, dry mass of leaves, stems, aerial part, root and total values not responded to treatments and the ages of analysis (Figure 2).
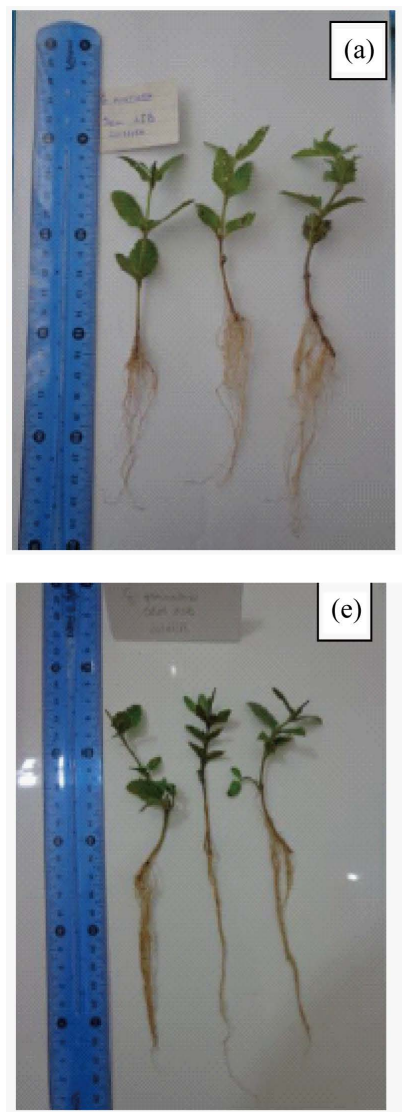
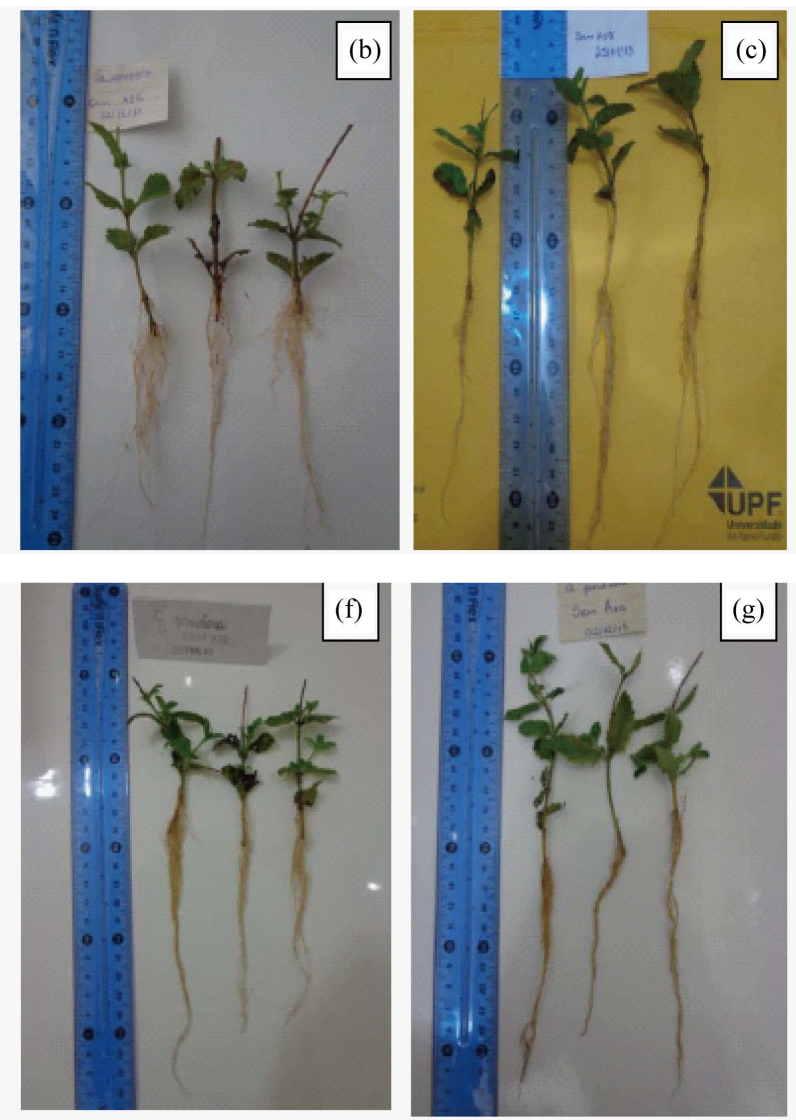
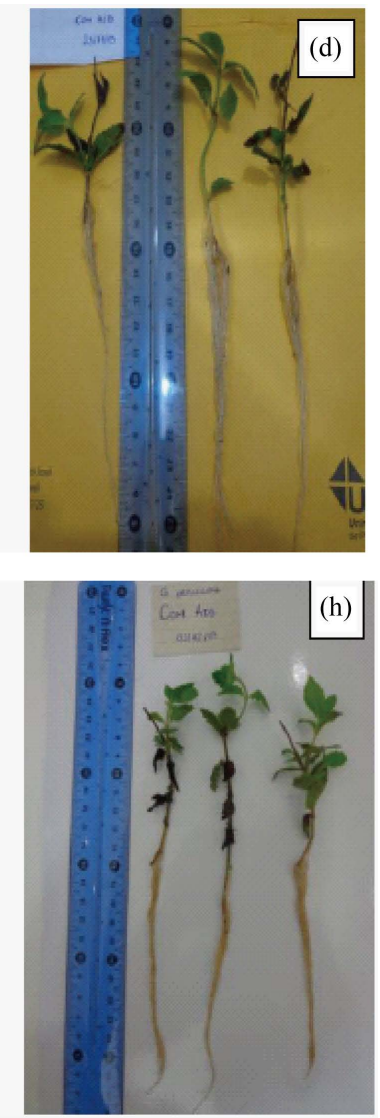

Figure 1. (a) and (b) G. peruviana cuttings, at 21 days of age, untreated and treated with IBA, respectively; (c) and (d) G. peruviana cuttings, analyzed after 24 days without treatment and treated with IBA, respectively; (e) and (f) G. peruviana cuttings, analyzed after 27 days without treatment and treated with IBA, respectively; (g) and (h) G. peruviana cuttings after 31 days without treatment and treated with IBA, respectively (Passo Fundo, 2013). 
The split of dried masses allows the estimation of growth rates that quantify the changes of mass in a given time interval [9]. The absolute growth rates (Figure 3(a)) and relative growth rates (Figure 3(b)) present results that diverge for the presence or absence of IBA and the age of analysis. The hormones are produced and transported by the plant, which will promote the development. The major groups of growth-regulating hormones are cytokinins, auxins, gibberellins. The auxin alone only induces swelling and enlargement of existing cells, requiring that cytokinin stimulates mitosis and bud formation [10]. The provision of auxin hormones without the other hormones participants in the development of the cuttings may thus becomes inefficient when the species

Table 1. Datas of plant height, live leaves average number, dead leaves average number per cutting,. average leaf length and number of shoots of $G$. peruviana treated or not with IBA at different ages (Passo Fundo, 2013).

\begin{tabular}{|c|c|c|c|c|c|c|}
\hline Age (days) & $\begin{array}{c}\text { IBA } \\
\text { Treatment }\end{array}$ & Plant height (cm) & $\begin{array}{c}\text { Live leaves } \\
\text { average } \\
\text { number (un) }\end{array}$ & $\begin{array}{l}\text { Dead leaves } \\
\text { average } \\
\text { number (un) }\end{array}$ & $\begin{array}{l}\text { Average leaf } \\
\text { length }(\mathrm{cm})\end{array}$ & $\begin{array}{l}\text { Number of shoots } \\
\text { (un) }\end{array}$ \\
\hline \multirow{2}{*}{21} & without & 7.90 & 8.67 & 0.67 & 1.97 & 1.33 \\
\hline & with & 7.13 & 6.00 & 2.00 & 1.83 & 1.67 \\
\hline \multirow{2}{*}{24} & without & 7.57 & 10.67 & 2.00 & 1.55 & 1.33 \\
\hline & with & 6.93 & 7.00 & 3.00 & 1.45 & 1.33 \\
\hline \multirow{2}{*}{27} & without & 8.90 & 9.00 & 0.33 & 1.47 & 1.00 \\
\hline & with & 7.13 & 14.67 & 2.33 & 0.99 & 1.67 \\
\hline \multirow{3}{*}{31} & without & 9.50 & 11.33 & 2.00 & 1.57 & 2.00 \\
\hline & with & 9.20 & 14.67 & 3.33 & 1.41 & 2.33 \\
\hline & CV (\%) & 15.58 & 34.40 & 99.66 & 19.72 & 45.97 \\
\hline
\end{tabular}

\begin{tabular}{|c|c|c|c|c|c|c|c|c|}
\hline 0.2000 \\
0.1500 \\
0.1000 \\
0.0500 \\
0.0000
\end{tabular}

Figure 2. Graph of the partitioned dry matter obtained from plants of G. peruviana treated or not with IBA at different ages (Passo Fundo, 2013).

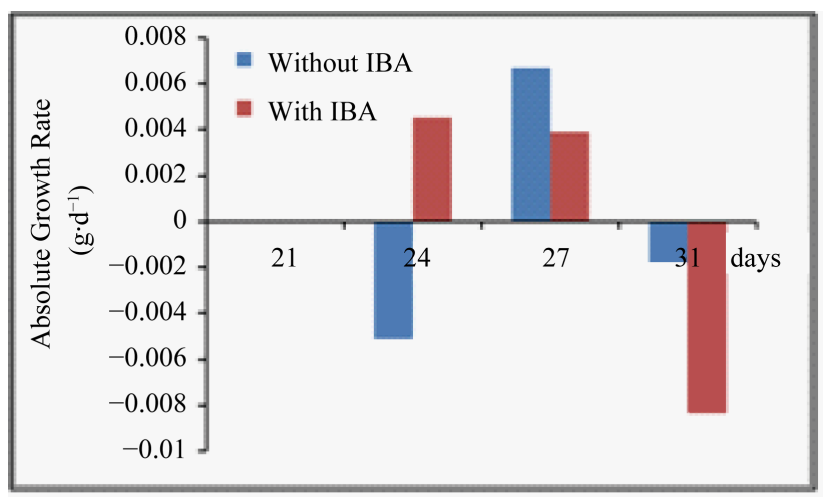

(a)

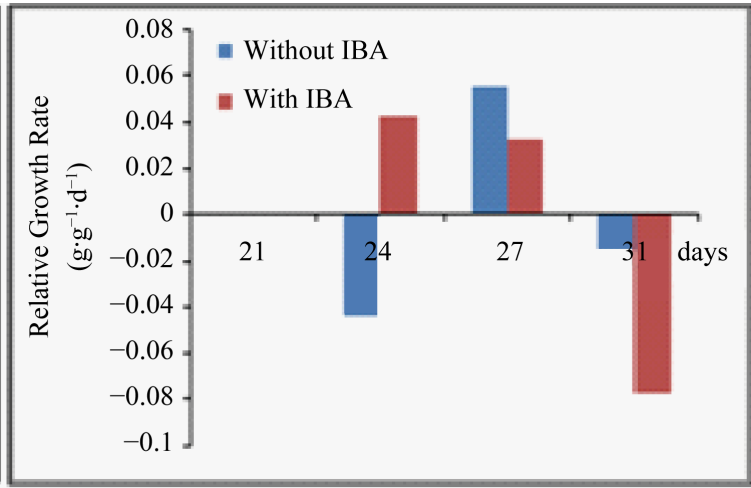

(b)

Figure 3. Average absolute growth rate obtained in the analyzes in four different times and relative growth rate obtained in the analyzes in four different times, respectively (Passo Fundo, 2013). 
have physiological restrictions in its vegetative reproduction. The species, with rooters nodes, can suffer when imbalance when treated with IBA.

Auxins constitute a group of growth regulators which has the greatest influence on root formation in cuttings, because they act in the formation of adventitious roots, the activity of cells in the cambium and growth of plants, influencing the inhibition of lateral buds and abscission [7]. The directing of reserves for creation and formation of roots may explain the apparent difference in leaf area between the IBA treatment and the control treatment because, although not differ statistically, the plants treated with IBA had inferior results (Figure 4). With species of the genus Glandularia, the use of IBA at $600 \mathrm{ppm}$ dose in mineral soil trend substrate caused the highest rooting [5].

The no significant difference between leaf area índex and total dry mass results in a no significant leaf area ratio (Figure 5(a)). So as not significant the leaf area index and liquid assimilation rate (Figure 5(b)), the latter presented a more significant drop in the final analysis to the treatment with IBA due to the increase in the leaf area ratio.

\section{Conclusions}

The result eliminates the use of this auxin in the vegetative propagation of the species, reducing its cost and making it viable for producers without access to specialized implements for floriculture. This facilitates the reproduction by cuttings of Glandularia peruviana in order to appreciate it as an ornamental plant that represents native biodiversity of the pampa biome.

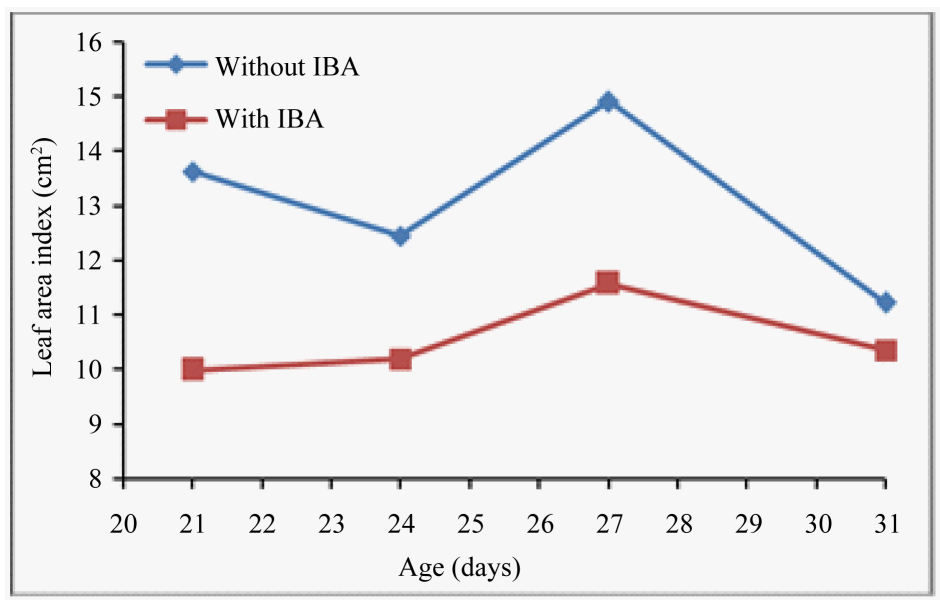

Figure 4. Graph of the average leaf area index obtained from plants of $G$. peruviana treated or not with IBA at different ages (Passo Fundo, 2013).

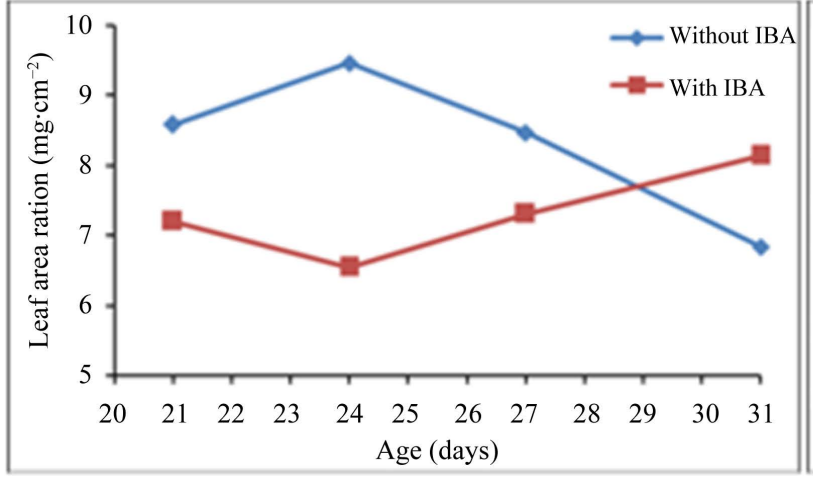

(a)

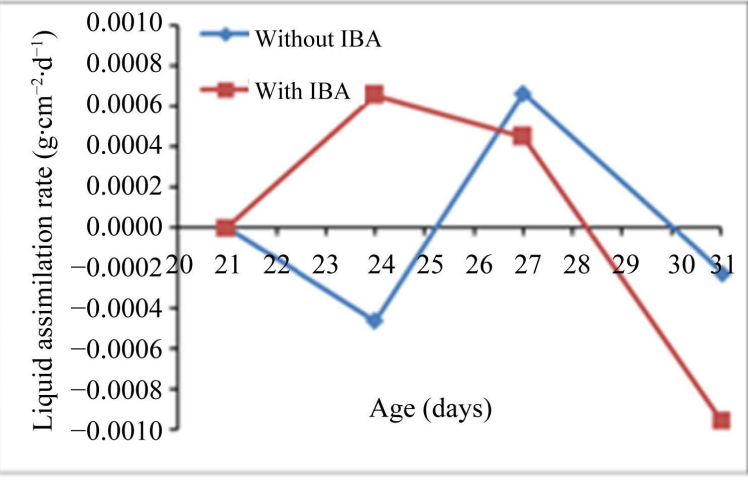

(b)

Figure 5. Graph of the leaf area ratio obtained from plants of G. peruviana treated or not with IBA at different ages and graph of liquid assimilation obtained in the analyzes in four different times, respectively (Passo Fundo, 2013). 
Further studies and projects are needed to evaluate the plant development in greenway and encourage the use of the species in landscaping.

\section{Acknowledgements}

The authors thank to University of Passo Fundo and Capes for Pos Graduation scholarship and the Dall'Agnese family for the financial support and encouragement.

\section{References}

[1] Thode, V.A. and Mentz, L.A. (2010) O gênero Glandularia J.F. Gmel. (Verbenaceae) no Rio Grande do Sul, Brasil. Acta Botânica Brasil, 24, 529-557. http://dx.doi.org/10.1590/S0102-33062010000200023

[2] Botta, S.M. (1993) Notas en el género Glandularia (Verbenaceae-Verbenoideae) III. Estudio taxonómico de las especies patagónicas. Parodiana, 8, 9-36.

[3] Mentz, L.A., Lutzemberger, L.C. and Schenkel, E.P. (1997) Da flora medicinal do Rio Grande do Sul: Notas sobre a obra de D’Ávila (1910). Caderno de Farmácia, 13, 25-48.

[4] Imhof, L., Badariotti, E., Betolli, F., Suárez, M., Facciuto, G.R., Benavente, A.G., Lopez, J.M., Molina, M.G. and Mangeaud, A. (2006) Estudio preliminar de propagación agámica en tres especies de Glandularia bajo distintos sustratos y dosis hormonales. Proceedings of III Congresso Argentino de Floricultura e VIII Jornadas Nacionales de Floricultura, La Plata, 7-10 November 2006, 227-231.

[5] de Campos, C.C. and Petry, C. (2007) Desenvolvimento de mudas de Glandularia sp. Gmelin obtidas de estaquia. Revista Brasileira de Biociências, 5, 327-329.

[6] Antunes, L.E.C., Chalfun, N.N.J. and Regina, M. de A. (2000) Propagação de cultivares de amoreira-preta (Rubus spp.) através de estacas lenhosas. Revista Brasileira de Fruticultura, 22, 195-199.

[7] Fachinello, J.C., Hoffmann, A., Nachtigal, J.C., Kersten, E. and Fortes, G.R. de L. (1995) Propagação de plantas frutíferas de clima temperado. 2nd Edition, Universidade Federal de Pelotas, Pelotas.

[8] Ponce, M.T., Guiñazu, M.E., Fioretti, S. and Cirrincione, M.A. (2010) Micropropagación de Glandularia, género nativo con potencial ornamental. Revista de la Facultad de Ciencias Agrarias, 42, 161-170.

[9] Silva, L.C., Beltrão, E. de M. and Amorim Neto, M.S. (2000) Análise de crescimento de comunidades vegetais. EMBRAPA-CNPA, Campina Grande.

[10] Galston, A.W. (1974) A Planta Verde. Ed. Perspectiva, São Paulo. 